\title{
Stage 0 Lung Cancer AJCC v8
}

National Cancer Institute

\section{Source}

National Cancer Institute. Stage O Lung Cancer A/CC v8. NCI Thesaurus. Code C136469.

Stage 0 includes: T is, N0, MO. T is: Carcinoma in situ. Squamous cell carcinoma in situ (SCIS). Adenocarcinoma in situ (AIS): adenocarcinoma with pure lepidic pattern, $3 \mathrm{~cm}$ or less in greatest dimension. N0: No regional lymph node metastasis. M0: No distant metastasis. (AJCC 8th ed.) 